\section{Agency Costs and Scarce Resources: Influences on Brazilian Franchising}

\author{
Eugenio Jose Silva Bitti ${ }^{1,+}$ (i) \\ ${ }^{1}$ Universidade de São Paulo, Ribeirão Preto, SP, Brazil \\ Vinicius Medeiros Magnani ${ }^{2, \Omega}$ (D) \\ ${ }^{2}$ Universidade de São Paulo, Ribeirão Preto, SP, Brazil \\ Bianca Thomazella ${ }^{3, \pm}$ (D) \\ ${ }^{3}$ Universidade de São Paulo, Ribeirão Preto, SP, Brazil
}

\section{ABSTRACT}

This paper revisits a traditional issue in literature on franchising: the contractual mix (i.e., the proportion between franchised and companyowned stores). We analyze 270 Brazilian chains to better understand the Brazilian scenario. We stress the dynamics of this proportion over time considering the perspective of monitoring costs and the difficulty of access to resources as possible explanations. Considering the moment of the Brazilian economy, it is pertinent and opportune to investigate the behavior of the chains in times of turbulence. Panel data covering the 2011-2016 period was analyzed through econometric tools. The results corroborate aspects related to monitoring and incentives advocated by the agency theory, that is: costs of monitoring in elevation due to the geographic dispersion induce a greater proportion of franchised stores. In addition, the concept of dispersion is extended to capture socioeconomic aspects of the different regions occupied by the chains. Effects related to restriction to scarce resources are also noted, but in a less unambiguous way.

Keywords: Franchising; Contractual mix; Agency theory; Resource scarcity.

\section{INTRODUCTION}

Studies based on agency theory suggest that higher monitoring costs of geographically dispersed outlets are an explanation for a larger proportion of franchised outlets. In this case, growing monitoring costs induce the chain manager to adopt stronger incentive mechanisms to align local agents' interests and behaviors. Franchise contracts materialize such incentive mechanisms by making the local agent a franchisee, who is the owner of local assets and, consequently, residual claimant of their unit (Gillis, Combs, \& Ketchen, 2014). On the other hand, the resource scarcity view suggests that the franchise arrangement is a solution to overcome resource constraints, such as capital and managerial capacity that chains must cope with to succeed. This is especially true in younger chains which still have difficulties in reaching production and promotion scale (Madanoglu \& Castrogiovanni, 2017). In short, in this perspective, franchisees represent more attractive sources of vital resources for the growth and consolidation of franchised chains. 
Although the agency theory literature has emerged from Rubin's (1978) criticisms related to "the capital marketing explanation of franchising", the two proposals have been combined since the 1990s. Studies such as those of Carney and Gedajlovic (1991), Combs and Castrogiovanni (1994), Combs and Ketchen (1999) indicate that a broader understanding of the franchising phenomenon is not possible (particularly in relation to the contractual mix) without considering elements of both theories taken together. This view was consolidated during the 2000 s, when a series of studies came out confirming the greater explanatory power of the composition of the two strands (Castrogiovanni, Combs, \& Justis, 2006; Combs \& Ketchen, 2003).

Concerning emerging markets in general, and Brazil in particular, there are few studies investigating the combined effect of agency costs and scarce resources on the contractual mix in franchised chains. An exception can be seen in Bitti, Aquino and Amato (2013), despite their study having only addressed agency problems in determining the proportion of owned and franchised stores. Moreover, Silva and Azevedo (2007) studied the use of plural forms (the coexistence of company-owned outlets and franchised ones in the same chain) in franchised networks. However, they applied an institutional perspective to compare chains operating simultaneously both in Brazil and France. Finally, Dant, Perrigot and Cliquet (2008) also addressed the issue of plural forms, developing a cultural perspective to compare the behavior of the contractual mix between Brazil, France and the USA.

Since franchising literature has almost ignored the Brazilian context, which constitutes a gap in this literature, we realize that it is convenient to verify both agency and resource scarcity issues in Brazilian franchising. Although the combined perspective of agency costs and scarce resources has already found many satisfactory responses in mature markets in Europe and the USA, the same cannot be said with respect to emerging markets, since there are considerable differences, for instance, in terms of institutional environment. The Brazilian case is even more interesting given to the continental dimensions of the country, the regional differences in terms of income and standard of living, and the huge economic turbulence the country has been going through since 2014 .

The research problem we address in this paper is related to the effect of both monitoring costs and scarce resources access capability over the contractual mix in Brazilian franchised chains in a longitudinal perspective. We analyze the effects of monitoring difficulties (costs) not only in terms of geographical distance between outlets and the chain headquarters, but also considering socioeconomic differences between the regions. Those differences, in our opinion, create even more difficulties in terms of coordination and control. We also contribute to the literature bringing a little-known effect on mix contractual: The positioning of outlets in shopping malls. Shopping malls exert some monitoring over their outlets, which generates some beneficial externalities for chains that locate outlets in this kind of market place. In addition, we investigate effects related to the life cycle of networks such as the chain size, maturity and the capital needed to open a new store.

To investigate the combined effects of agency costs and scarce resources on the contractual mix over time, we use panel data on a sample of 270 chains covering the 2011-2016 period. Our econometric procedure includes a model that has never been used before to analyze the contractual mix: a fractional response model. This method is applied in conjunction with more orthodox models to test our hypotheses. The results confirm the influence of the monitoring costs in the contractual mix setup. However, the behavior of variables, such as size and maturity, indicate that a traditional scarcity resource hypothesis holds true: The property redirection (more company-owned outlets associated with growth and aging). 


\section{THEORY AND HYPOTHESES}

In the agency theory view, under the conditions of low monitoring costs, companyowned outlets, despite their lower-powered incentive mechanisms, are more efficient than franchised outlets (Windsperger \& Dant, 2006). However, with increasing dispersion among outlets, both uncertainty and opportunities to undesired behaviors of the local agents also increase, making the franchise option more attractive to the franchisor. The franchising alternative is especially interesting in cases where the local agent's performance is the determining factor for the success of the local operation, either controlling costs or managing other unit employees (Maness, 1996). That is, franchising tends to prevail in chains with scattered units in which local decisions are more difficult to assess (Minkler, 1992) and where distance makes direct observation costly (Brickley \& Dark, 1987; Combs, Ketchen, $\&$ Short, 2011). From this perspective, monitoring capacity would be a limiting factor for chain growth (Garg, Priem, \& Rasheed, 2013). On the other hand, franchising could help chains to grow faster by reducing the need of monitoring along the growth process (Norton, 1988; Thompson, 1994). By linking the agent's compensation to their outlet performance, a higher level of contract self-enforcement is feasible (Rubin, 1978).

In addition to ex post concerns related to ensuring that the local agent delivers the promised level of effort (a moral hazard issue), franchising reduces ex ante expenditures with both search and selection of these agents (Antia, Zheng, \& Frazier, 2013). Adverse selection problems can be aggravated if the partner selection process occurs in places with great physical or cultural distance from the firm's HQ. Incumbent employees for the position of company-owned outlet manager could misrepresent their real skills and knowledge levels, which would raise the cost of the process of attracting and hiring new managers. In adopting the franchise arrangement, some barriers are established in relation to individuals who are poorly qualified for the operation. Considering the need for investment by the franchisees (Dnes, 1992), as well as other pre-qualification standards required by the chain, one could expect that individuals applying to enter the system will have greater managerial capacity (Kashyap, Antia, \& Frazier, 2012).

In short, when franchising a set of units, the chain invests in an incentive mechanism to save on monitoring costs. The geographical dispersion of the units makes this new combination of monitoring and incentive - resulting from franchising - generate a result superior to the combination resulting from the exclusive use of company-owned outlets (Brickley, Dark, \& Weisbach, 1991; Combs \& Ketchen, 1999; Lafontaine, 1992). Thus:

H1: The greater the geographic dispersion of the chain, the greater the proportion of franchised outlets.

Our study also seeks a new meaning for the concept of "dispersion" to capture a more qualitative nuance. We consider the fact that Brazil has marked inequality characteristics between its different regions and states. In other words, two chains may have a similar level of geographic dispersion in terms of distance but occupy very different cities in terms of socioeconomic indicators. The literature on agency initially envisaged greater intensity in the use of franchised outlets in regions further away from large urban centers (Rubin, 1978; Lafontaine \& Shaw, 2005), even with respect to problems related to physical distance. More recent arguments have pointed other issues related to the risk of operating units in markets that are unfamiliar to chain management (Castro, Mota, \& Marnoto, 2009). We propose that part of the specificities of these new markets is represented in the socioeconomic differences, especially considering the continental dimensions of Brazil.

The Human Development Index (HDI) is an indicator of socioeconomic development measured by the United Nations Development Program (UNDP). It is calculated using three parameters: income, education and health. For the health dimension, the calculation considers life expectancy. For education, the adult literacy rate and the schooling levels of 
the population are evaluated. In general, the GDP per capita is used for income, considering purchasing power parity (PPP), to allow comparability between countries. The parameters are treated and combined, assuming a value between 0 and 1 (United Nations Development Program [UNDP], 2018). The UNDP calculates the HDI of Brazilian municipalities every ten years (last evaluation in 2010).

These data provide interesting insights into the study: on average, municipalities with the highest HDI growth between 1990 and 2010 are the poorest ones, probably because of social programs undertaken by the Brazilian government since the stabilization of the economy in the 1990s. This is verified in the HDI data of the municipalities. The correlation between the 2010 HDI and the HDI rate of change between 1990 and 2010 is $69.74 \%$. This fact illustrates the growth of the middle class and, therefore, the emergence of alternative markets to the large cities of the South-Southeast axis. It is assumed that the expansion towards less mature markets raises greater operational risks for the chains, so that a greater use of franchisees is expected in this expansion process. Therefore:

H2: The greater presence of chains in less developed cities is associated with a higher proportion of franchised outlets.

However, if complexity (and costs) of monitoring units rises as spatial dispersion increases, one could expect that this effect should be mitigated by some operational characteristics that make the monitoring effort more efficient. One of these characteristics is the siting of units in shopping malls. In Brazil, the rent charged by shopping malls usually has both a fixed and a variable portion, usually a percentage charged on the store revenue (Lemos \& Rosa, 2003). Due to this variable expense related to the revenue (like royalties charged by the franchisors), the management of the shopping mall maintains some level of monitoring on the established stores (Pashigian \& Gould, 1998). This applies not only to financial matters, but also to other aspects related to the operation of the unit (service, cleaning, store facade, etc.).

In addition, stores sited in shopping malls benefit from the "cumulative attraction" effect (Teller \& Schenedlitz, 2012). That is, aspects, such as practicality, comfort and convenience (maximizing the use of purchasing time, reducing travel costs for diversified purchases) and - in the case of Brazil - safety create advantages to the consumer that, according to a store point of view, can boost both sales volume and customer's willingness to pay a premium price (Teller \& Schenedlitz, 2012). In parallel, Hsu, Kaufmann and Srinnivasan (2017) suggest that the franchisor will pursue the strategy of maintaining the property of the most profitable outlets.

That is, there are at least two influence factors motivating the chain that places stores in shopping malls to possess more company-owned outlets: (i) monitoring exerted by shopping mall management and (ii) greater potential for profitability. According to the Brazilian Franchising Association (ABF), about $34.5 \%$ of all stores established in shopping malls in Brazil belong to franchise chains (Associação Brasileira de Franquias [ABF], 2017). According to the Brazilian Association of Shopping Malls (ABRASCE) (2018), there are 571 shopping malls in Brazil, which offer 102,300 commercial locations. The entire sector handled almost 50 billion USD in 2017. Due to both data and the logic linking franchised networks to the shopping malls, we expect that chains that typically have more stores in this type of commercial condominium will have a higher proportion of their company-owned outlets. Formally:

H3: The greater the proportion of chain outlets sited in shopping malls, the lower the proportion of franchised outlets.

In addition to the effect of agency costs on the contractual mix, our model also considers the effect of potential resource scarcity in the sample we analyze. These aspects are jointly employed as a way of increasing the explanatory power of the model. This approach is derived from the resource-based view (Castro, Mota, \& Marnoto, 2009) and it is considered 
BBR

16,4

the first theoretical lens that sought to explain the adoption of the franchised arrangement (Combs \& Ketchen, 1999). Seminal works, such as Oxenfeldt and Kelly (1968) and Caves and Murphy (1976) developed arguments based on the assumption that chain management would prefer to operate only with its own stores, but they choose franchise outlets as a way to leverage the chain growth by providing capital and capacity at a cost that is much lower compared to other available sources on the market (Norton, 1995).

Combs and Ketchen (1999) also list two reasons why franchising could be a low-cost capital alternative. First, from the franchisee perspective, there is no separation between ownership and control with respect to the franchisee investment. As a result, agency costs that are typically faced by passive investors are less shocking, which reduces possible expenditures with governance mechanisms and protection of investments. Therefore, the return required by franchisees tends to be lower compared to other sources of capital. Secondly - and as already mentioned in this text - adverse selection problems tend to be reduced in franchise relationships, given all the money franchisee must invest in the relationship. This means that the recovery of invested capital is strongly conditioned to the franchisee performance, which would attract individuals both aware and better skilled with respect to transaction. In turn, passive investors would not face such a low level of information asymmetry, prompting them to demand a larger return on their investments.

Previous research based on resource scarcity theory emphasizes the issue of property redirection when growth constraints are alleviated (Windsperger \& Dant, 2006). That is, under the assumption that chains prefer to own the outlets as much as possible, fundamental resources such as capital and local knowledge are the main reasons to franchise units. Therefore, as those constraints are relieved, franchised chains either stop selling new franchises or start to buy the current ones back. This logic leads to the inference that supports one of the main criticisms on resource scarcity view: If franchisees were just a cheaper resource provider for small, young chains, franchising would be a temporary phenomenon (Martin, 1988).

As a chain becomes larger, its ability to raise resources at a lower cost would increase, rising the opportunity cost related to franchising its outlets. As a result, the proportion of company-owned outlets would increase over time until, at the outset, the chain became vertically integrated. This result is neither verified in the practices of the franchise sector, nor is it supported by the empirical literature, but some studies have managed to capture increases in the proportion of company-owned stores due to the relief of resource constraints (Dant, Perrigot, \& Cliquet, 2008). One can expect that such constraint relief would come from gains in size and maturity.

Large chains would tend to reduce the franchised proportion to a large extent due to two issues. First, the larger the chain, the greater the problem of adverse selection and the greater the risk of the free-riding effect (Gomez, González, \& Vazquez, 2010). The positive relation between the size of the chain and the risk of free-riding is generally derived from the brand value, which in turn, is associated with the size. Valued brands tend to be associated with products and services of recognized quality, which creates reputation and generates customer satisfaction, that, in turn, tends to imply larger sales, margins or market share. Costs associated with ex ante adverse selection and ex post monitoring costs would reduce opportunity costs of operating more own stores. Secondly, the size of the chain would allow a scale to be obtained in the capture of resources, whether capital or local knowledge (Caves \& Murphy, 1976). Therefore, the option for a greater proportion of own stores becomes more attractive. Thus:

\section{H4: The larger size of the chain is associated with the smaller proportion of franchised outlets.}

Regarding size, we expect that maturity will also affect the contractual mix. Previous research has suggested that franchised chains in the early stages of their lifecycle make 
contractual mix decisions which are different from decisions made by more mature chains (Lafontaine \& Kaufmann, 1994; Martin, 1988; Shane, 1996) Hypotheses predicting a negative relationship between chain maturity and the proportion of franchised outlets can be derived from both agency theory and resource scarcity view. From agency perspective, maturity increases the level of familiarity of the chain concerning both the business concept and management of the chain. Much of the energy devoted to growth during the development phase can be redirected to the management of franchisees and contract managers for company-owned stores (Castrogiovanni, Combs, \& Justis, 2006). Therefore, tasks related to monitoring and controlling the agent effort as well as measuring and assessing outlet performance tend to be better performed by the chain management, which could mitigate the need for incentives, resulting in more company-owned outlets.

The perspective of scarce resources, in turn, understands that many of the constraints that afflict chains in their early life cycle stages lose strength as the chain matures (Madanoglu $\&$ Castrogiovanni, 2017). The support received by this view is not unequivocal. While more mature franchised chains are more likely to survive, Bardonaba-Juste, Lucia-Palacios and Polo-Redondo (2011) verify exactly the opposite. Still considering the dynamics of the life cycle, Cliquet (2000) argues that, typically, during the early stages of the life cycle, store density tends to be lower than during the maturity phase, which would impact the contractual mix. At its beginning, seeking to increase the market occupation, the chain would choose to attract franchisees to sustain growth. However, with maturity, the emphasis would be on the outlets profitability, with the conversion of the most profitable units into their own stores.

H5: The more experienced the chain becomes, the lower the expected proportion of franchised outlets.

Still considering the difficulty of accessing resources, which are important for the chain success, we verified the effect of the costs of installing a new unit on the contractual mix. Opening a new outlet involves investing resources and taking risks, and the success of the operation is largely moderated by the managerial capacity and local level of knowledge of that unit (Cliquet \& Pénard, 2012). Therefore, attracting partners to share such costs and risks could be an interesting option from the chain point of view. In addition, of course, external variables, such as changes in the pattern of local competition, consumer preferences, and economic variables like unemployment and income, will affect unit performance. This implies that increasing the cost of installation to open a new store in conjunction with worsening of the adjacent market can make the option for franchising increasingly interesting.

Brazil has been experiencing a severe economic and political crisis since the latter half of 2014. During this period, the country experienced a severe recession and many uncertainties. Virtually all the economic indicators have experienced a significant worsening. To cite some examples, first, the Brazilian GDP witnessed two consecutive falls: $-3.8 \%$ in 2015 and $-3.6 \%$ in 2016 (it remained practically stable in 2017). Second, the unemployment rate increased almost 80\% between 2013 and 2017 (from $7.20 \%$ to 13.02\%). One can expect that such a scenario could impact Brazilian franchising sector. Our model seeks to capture these effects on contractual mix.

Turbulence has affected Brazilian franchising industry as partially indicated in Table 1 . According to the ABF (2014), there was a reduction in the number of franchised chains in Brazil and sales were seriously affected between 2013 and 2017 as well. But it is noteworthy that both the number of units and the number of jobs grew. Although chain growth is not the focus of our research, we expect this growth to have occurred with more franchised stores, following the rationale of scarce resource view. Specifically, considering the presented scenario, we expect that the growth of the costs of installing new stores is associated with an increase in the proportion of franchised stores. Therefore, 
Table 1 - Brazilian Franchising Sector: Performance (source: ABF)

\begin{tabular}{|c|c|c|c|c|}
\hline Year & $\begin{array}{c}\text { Brazilian Franchising } \\
\text { Turnover (Billion USD) * }\end{array}$ & Redes & Total Stores & Employees \\
\hline 2013 & 54.82 & 2,703 & 114,409 & $1,029,681$ \\
\hline 2014 & 54.76 & 2,942 & 125,641 & $1,096,859$ \\
\hline 2015 & 41.90 & 3,073 & 138,343 & $1,189,785$ \\
\hline 2016 & 43.34 & 3,039 & 142,593 & $1,192,495$ \\
\hline 2017 & 51.17 & 2,845 & 146,134 & $1,193,568$ \\
\hline
\end{tabular}

\section{H6: The higher the costs for installing stores, the greater the proportion of franchised} outlets.

\section{METHODOLOGY}

Figure 1 schematically charts the set of hypotheses formulated as an additive model. The study contemplates a longitudinal panel data analysis, for the 2011-2016 period. The objective was to constitute a fully balanced panel to enhance the result robustness. After crossing the sources of information used, we obtained a sample with a little more than 300 franchised chains. However, it should be noted that it was necessary to contact the management of some chains to check if there were either any conflicting or even missing information. After this last effort, a 270-chain balanced panel was obtained.

The panel data methodology used has many benefits, such as: The reduction of collinearity between the explanatory variables of the model and the analysis of larger samples since it considers several individuals (chains) over time. Moreover, it allows the increase of degrees of freedom in the estimates of the proposed model (Hsiao, 1996). Tests were conducted to verify a method that best fit the data for estimation. Just before the tests were carried out, a small within variation of the variables was observed, making it impossible to estimate the model by fixed effects since the parameters would be imprecisely estimated (Wooldridge, 2010). Regarding the estimation by random effects, there are no arguments that support the hypothesis that the individual effects of the chains do not have any type of relation with the model explicative variables. Thus, the linear estimation method adopted was the Pooled Ordinary Least Squares (POLS).

In addition to the argument about the estimation method used, it is worth to emphasize the nature of the construction of the model dependent variable. According to Papke and

Figure 1 - Theoretical Model of Study

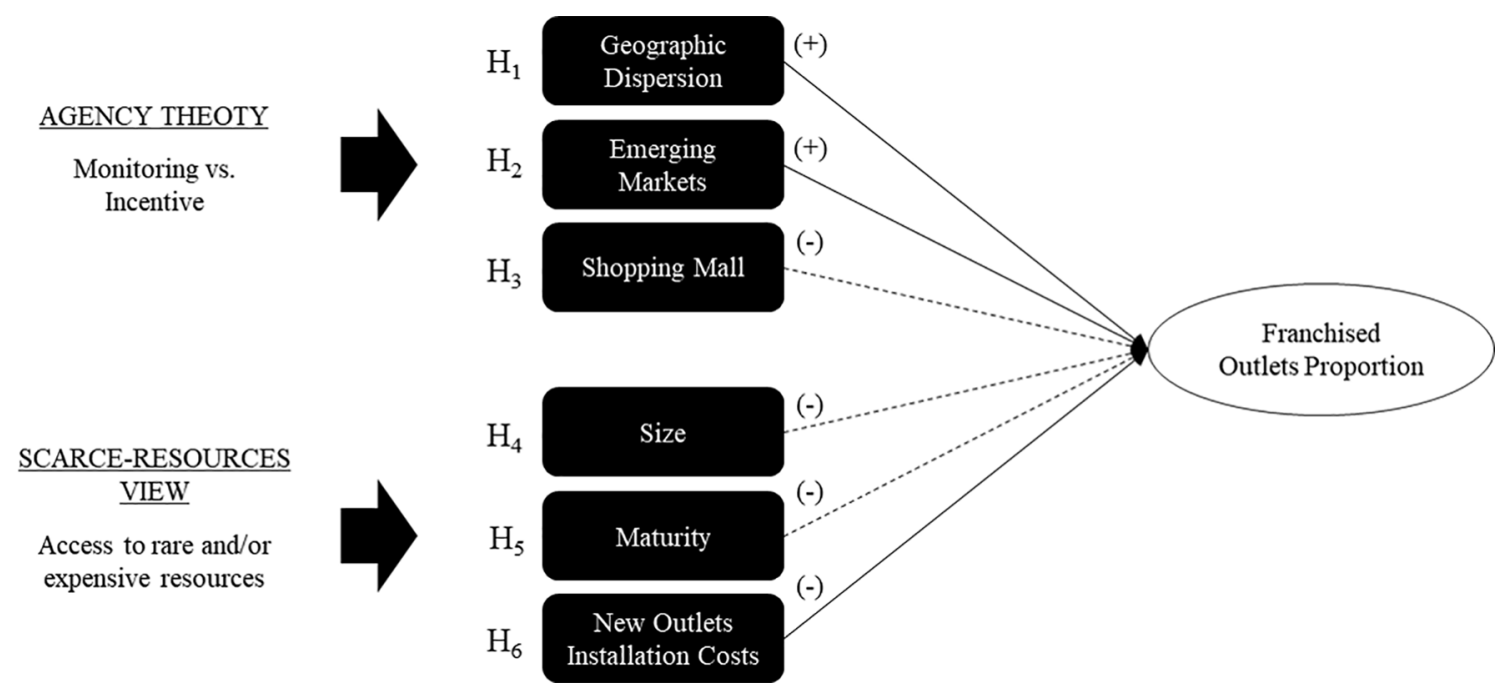

Source: Developed by the authors. 
Wooldridge $(1996,2008)$, when the variable is fractional, it is also necessary to estimate the model proposed by the fractional response methodology applied to panel data. This methodology is based on the non-linear estimation of the model by the logistic or probabilistic response function. In the case of the estimation of the work model, the logistic function was chosen, since it produces computationally simpler estimators in the presence of unobserved heterogeneity (Papke \& Wooldridge, 1996). Moreover, the advantages of estimating the model by a nonlinear response function is in the best fit of the model function to the distribution of the fractional dependent variable.

The hypotheses were tested with data from different sources of information. The Official Franchising Guide of $\mathrm{ABF}$ is an annual publication offered to the interested public, which is also available free of charge in its electronic version at the ABF website. Through this publication, the chains associated with the ABF inform interested parties the basic characteristics, such as: area of operation, contact, franchise fees, current size of the chain in terms of number of units (own and franchised), investment required, among other information. The chains do not detail the address of their units in the yearbook, so it was necessary to use a second source of information: the internet address of the sample chains. For each chain, data on occupied cities were tabulated, with the number of outlets per city rising and physically disposed in some type of commercial condominium or equivalent (shopping centers, shopping malls, airports, university campuses, etc.). The collection of these data occurred in three different time periods: 2011, 2014 and 2016. Once the occupied municipalities were known, the IBGE (Brazilian Institute of Geography and Statistics) website was used to collect data on longitude and latitude, such as socioeconomic information.

\subsection{DEPENDENT VARIABLE}

Frequently, in franchising literature, the term "contractual mix" is used to refer to the proportion of owned and franchised stores. Such nomenclature will be adopted herein. The proportion of franchised outlets (MIX) is used to represent the use of plural forms. To obtain this variable, we divide the number of franchised stores by the number of the total number of stores.

\subsection{INDEPENDENT VARIABLES}

Two variables are used to capture, in an additive way, the difficulty of monitoring due to the dispersion of the chain. The first one (GEODIST) is more traditional in relation to agency literature because it represents the geographic distance from one unit to the other and from the franchisor's HQ. Thus, it is inferred that more dispersed chains have greater monitoring complexity in comparison to more concentrated chains, all else held constant. To operationalize GEODIST, we used data from the cities where chains operate outlets to capture how distant the outlets in a chain are from one another (and from the franchisor's HQ). The variable assumes larger values for more dispersed chains. As already mentioned, unit address data were collected in 2011, 2014 and 2016. However, the panel contemplates the 2011-2016 period, therefore, we have missing values for the years 2012, 2013 and 2015. Such missing values were fulfilled assuming linearity in two stages: between 2011 and 2014, to fill the years of 2012/2013; and between 2014 and 2016, to fill the year 2015. Such a strategy was employed to generate a data panel as balanced as possible since removing years of 2012, 2013 and 2015 in the panel data would reduce the number of observations in half, which could lead to potential effects of attrition bias, that is, the omission of observations with significant effects on the franchise population of the study.

Then, the latitude and longitude of the cities were used to characterize the variable, applying the Euclidean distances. We considered that chains with groups of concentrated 
BBR

16,4

units are more easily monitored than chains with units which are more scattered throughout the Brazilian territory. Thus, a cluster analysis was applied to define groups of units that each chain presents in order to take into account the distance between the groups and not only the distance between units. Finally, the variable was created by adding, for each chain, the Euclidean distance between the stores of each group and the Euclidean distance of the groups. Thus, the value of the dispersion variable is a sum of the Euclidean distances, with higher values for chains without many concentrated groups and lower ones for chains with more compact location strategies.

The second variable capturing the issue of dispersion takes into account a more qualitative nuance. The regions of the country indicate considerable differences in terms of socioeconomic pattern. While the South and Southeast regions account for 92 of the 100 best-ranked municipalities on the Human Development Index (HDI) released by the United Nations Development Program (UNDP) for 2010, only two North/Northeast municipalities appear in the top 200 list. Thus, our model considers not only the geographical dispersion itself, but also the socioeconomic differences between the cities in which the chains operate their outlets. We operationalize the variable VARHDI to capture such differences using the HDI.

Before the operation of the variable VARHDI, a previous analysis of the HDI data for the Brazilian municipalities was carried out. As previously mentioned, UNDP has developed the measurement of the index for Brazilian municipalities every 10 years since 1990 (i.e., three surveys to date). The correlation between the percentage variation between the HDI of the municipalities of Brazil between 1990 and 2010 and the HDI of 2010 of the same is negative in almost $70 \%$. In other words, the municipalities with highest growth in terms of HDI are precisely the poorest ones. We calculate the average HDI per chain in our sample considering the HDI of all the cities where the chain has operations. We do that using UNDP HDI reports for the following years: 1990, 2000 and 2010. Finally, the percentage change between 1990 and 2010 was calculated, which resulted in the definitive characterization of the variable VARHDI. Thus, the variable captures not only the eventual search of the chain by emerging markets in the Brazilian scenario, but also the risk associated with this expansion strategy, considering that such markets are still in the maturation process.

The third variable (MALL) captures the presence of outlets in shopping malls as previously discussed in the $\mathrm{H} 3$ hypothesis development. For this purpose, the percentage of the outlets present in this kind of commercial enterprise was calculated. Such information is accessible through the addresses of the chain units. The fourth independent variable is the SIZE, which is operationalized by multiplying the total number of units by the average turnover of the units. Both information is available in the ABF Annual Report.

In order to capture the degree of maturity of the chains, we use the total time of existence of the chain (AGE) as well as the number of years from the inception of the franchisor until the year of observation (TFRANCHISE). In addition, considering that both variables represent different constructs, despite presenting a high correlation pattern (see Table 3), a principal component analysis was performed to obtain the MATURITY variable from these two original variables. Finally, the variable CAPINVST represents the investment demanded from franchisees to install a new outlet. This information is also available in the $\mathrm{ABF}$ annual report. However, it is informed in the form of a range (minimum and maximum values). We choose to take the minimum range because the choice of the average could add some bias in the models. In addition, we intend to capture micro-franchise strategies, which have been increasing lately because of the economic turbulence that the country has been experiencing since the end of 2014. 


\subsection{Control variables}

The first applied control variable is a dummy for foreign chains. Previous studies have shown that aspects, such as cultural distance, economic instability, and institutional complexity encourage foreign networks to enter in emerging markets to seek local agents to operate the brand in these countries (Baena, 2012; Fladmoe-Lindquist \& Jacque, 1995). It has been common to observe multinational franchising networks employing mastersfranchising models in Latin American countries, such as RE/MAX and McDonald's. Thus, the strategy of foreign networks operating in Brazil for the contractual mix differs from the strategy of the national networks, which demands the need to control such endogeny.

Dummies were also applied representing the operating sector of the chain. The present study adopted a taxonomy for the designation of the sectors. This occurs for three reasons. First, the taxonomy published by the ABF brings together (in the same sector) chains with very different operational structures. Second, there are changes in the taxonomy employed by the ABF over the years, with sample chains shifting from year to year. Finally, some sectors would be under-represented, for some of the years covered by the data panel. Thus, the following taxonomy is adopted: (i) food, (ii) clothing, (iii) services in general, (iv) trade and services (goods and/or services are offered in units), health services, (vii) cosmetic services, (viii) cosmetic products. It should be noted that areas involving human health or products/services related to beauty and aesthetics were individualized due to a greater risk relative to the consumption of the product offered. Table 2 presents a summary of our independent variables, their meaning, symbols, and expected signs concerning our dependent variable.

\begin{tabular}{cccc}
\multicolumn{2}{l}{ Table 2 - Variables Summary } \\
\hline Hypotheses & Independent Variable & Symbol & $\begin{array}{c}\text { Expected Sign Related to the } \\
\text { Dependent Variable (MIX) }\end{array}$ \\
\hline H1 & Geographic Dispersion & GEODIST & + \\
H2 & Emerging Markets in Brazil & VARHDI & + \\
H3 & Proportion of outlets in shopping malls & MALL & - \\
H4 & Size of chains & SIZE & - \\
H5 & Maturity of chains & AGE & - \\
& & TFRANCHISE & - \\
H6 & Initial investment to open a new outlet & MATURITY & CAPINVST
\end{tabular}

BBR

16,4

Source: Research data (2011 to 2016).

Table 3 - Descriptive Statistics

\begin{tabular}{ccccccc}
\hline Variables & Average & Median & $\begin{array}{c}\text { Standard } \\
\text { Deviation }\end{array}$ & Minimum & Maximum & Observations \\
\hline MIX & 0.847 & 0.928 & 0.205 & 0.000 & 1.000 & 1,620 \\
DISTGEO & $79,741.12$ & $1,627.35$ & $462,918.95$ & 0.00 & $9,264,576.83$ & 1,620 \\
VARHDI & 0.01054 & 0.01050 & 0.00080 & 0.00800 & 0.01375 & 1,620 \\
MALL & 0.444 & 0.400 & 0.379 & 0.000 & 1.000 & 1,620 \\
SIZE & 11,229 & 3,225 & 37,241 & 54 & 598,230 & 1,620 \\
AGE & 24.95 & 20.00 & 17.44 & 2.00 & 136.00 & 1,620 \\
TFRANCHISE & 13.35 & 12.00 & 8.34 & 1.00 & 62.00 & 1,620 \\
CAPINVST & 174.95 & 130.00 & 183.63 & 0.50 & $2,000.00$ & 1,620 \\
FOREIGNERS & 0.0556 & 0.0000 & 0.2291 & 0.0000 & 1.0000 & 1,620
\end{tabular}

Source: Research data (2011 to 2016). 


\section{RESULTS AND ANALYSIS}

After the estimation of the model by the methodology mentioned above, we performed tests to verify the existence of multicollinearity between the explanatory variables of the model as, for instance, the correlation matrix analysis and the Variance Inflation Factor. We also applied Breusch-Pagan and Cook-Weisberg tests to verify the existence of the homoscedasticity in residues, as well as the Shapiro-Wilk and Shapiro-France tests to verify the normal distribution of residues. It should be noted that the variables were normalized by the "z-score" command of the STATA software. Table 3 presents the descriptive statistics of the variables proposed by the model and Table 4 indicates Pearson's correlation coefficients.

Table 5 presents results of the estimated models. The results of the proposed statistical tests are shown at the bottom of Table 5. Concerning the homoscedasticity of the residues, for the four estimated models, there is no homoscedastic variances. Therefore, the models were estimated using the variance matrix and robust covariance. For the assumption of multicollinearity, Table 2 shows that there is no high correlation between the model variables, except between the SIZE and CAPINVST variables. Thus, the VIF test was performed, which presents a less than 5 average for all models, which permits us to infer that the estimates do not suffer from multicollinearity problems. Finally, the normality test of the waste distribution presents statistics that reject the test hypothesis.

Chow, Breusch-Pagan and Hausman tests indicate that the best estimator is obtained using fixed effects, but as already mentioned, the model was estimated by the POLS and by the nonlinear fractional response (fracreg) applied to panel data. Models 1 and 2 were estimated with the variables AGE and TFRANCHISE (representing different constructs). However, when we observe both a distinct relation on the dependent variable and a high correlation between the two variables, we chose to perform a factor analysis between the two variables that represent the MATURITY of the chains. Therefore, models 3 and 4 were estimated replacing the variables AGE and TFRANCHISE by the variable MATURITY.

Almost all coefficients in our models are significant at 1\%, except the coefficients of the DISTGEO in models 1 and 3, estimated by POLS, which were significant at 5\%. Overall, the schematic model proposed, shown in Figure 1, is strongly supported by the data. The first hypothesis $\left(\mathbf{H}_{1}\right)$ proposes a positive relation between the geographic dispersion of the chains and the proportion of franchised outlets, which is supported by all the models. This result corroborates the more traditional proposition of the agency theory for franchising already verified in previous studies acclimated in the most diverse scenarios (Martin, 1988; Norton, 1988; Fladmoe-Lindquist \& Jacque, 1995).

$\mathbf{H}_{2}$ is also strongly supported, since a positive and significant relationship between the level of development of the city and MIX was found in the four estimated models. Here again, a traditional prediction of agency and transaction cost economics (Baena, 2012) is confirmed (the use of franchisees in higher risk locations), now with the collaboration of an innovative metric: the use of socioeconomic data from cities. The negative relation

\begin{tabular}{lllllllll}
\multicolumn{2}{l}{ Table 4 - Correlation Matrix } \\
\hline Variables & MIX & DISTGEO & VARHDI & MALL & CAPINVST & AGE & TFRANCHISE & SIZE \\
\hline MIX & 1 & & & & & & & \\
DISTGEO & 0.091 & 1 & & & & & & \\
VARHDI & 0.230 & 0.211 & 1 & & & & & \\
MALL & -0.175 & -0.111 & -0.268 & 1 & & & & \\
CAPINVST & -0.219 & 0.007 & -0.208 & 0.212 & 1 & & & \\
AGE & -0.036 & 0.179 & 0.095 & 0.015 & 0.135 & 1 & & \\
TFRANCHISE & 0.199 & 0.222 & 0.198 & -0.148 & 0.091 & 0.487 & 1 \\
SIZE & -0.104 & 0.298 & 0.147 & -0.063 & 0.441 & 0.222 & 0.2633 & 1
\end{tabular}

Source: Research data (2011 to 2016). 
Table 5 - Estimated Models - AGE and TFRANCHISE

\begin{tabular}{|c|c|c|c|c|}
\hline \multirow{2}{*}{$\begin{array}{l}\text { Dependent Variable } \\
\text { Models }\end{array}$} & \multicolumn{4}{|c|}{ MIX } \\
\hline & 1 & 2 & 3 & 4 \\
\hline Independent Variables & Coef. [T-Stat. ] & Coef. [T-Stat. ] & Coef. [T-Stat. ] & Coef. [T-Stat. ] \\
\hline \multirow[t]{2}{*}{ DISTGEO } & 0.007 & 1.398 & 0.007 & 1.371 \\
\hline & {$\left[2.40^{* *}\right]$} & {$\left[4.71^{* * *}\right]$} & {$\left[2.37^{* *}\right]$} & {$\left[4.64^{* * *}\right]$} \\
\hline \multirow[t]{2}{*}{ VARHDI } & 0,037 & 0.270 & 0.040 & 0.306 \\
\hline & {$\left[6.76^{* * *}\right]$} & {$\left[6.01^{* * *}\right]$} & {$\left[6.96^{* * *}\right]$} & {$\left[6.37^{* * *}\right]$} \\
\hline \multirow[t]{2}{*}{ MALL } & -0.026 & -0.200 & -0.026 & -0.214 \\
\hline & {$\left[-4.02^{* * *}\right]$} & {$\left[-4.16^{* * *}\right]$} & {$\left[-3.80^{* * *}\right]$} & {$\left[-4.24^{* * *}\right]$} \\
\hline \multirow[t]{2}{*}{ CAPINVST } & -0.032 & -0.183 & -0.033 & -0.185 \\
\hline & {$\left[-5.59^{* * *}\right]$} & {$\left[-6.28^{* * *}\right]$} & {$\left[-5.75^{* * *}\right]$} & {$\left[-5.96^{* * *}\right]$} \\
\hline \multirow[t]{2}{*}{ AGE } & -0.029 & -0.217 & & \\
\hline & {$\left[-3.70^{* * *}\right]$} & {$\left[-4.73^{* * *}\right]$} & & \\
\hline \multirow[t]{2}{*}{ TFRANCHISE } & 0.053 & 0.504 & & \\
\hline & {$\left[9.06^{* * *}\right]$} & {$\left[8.82^{* * *}\right]$} & & \\
\hline \multirow[t]{2}{*}{ MATURITY } & & & 0.019 & 0.135 \\
\hline & & & {$\left[3.72^{* * *}\right]$} & {$\left[2.90^{* * *}\right]$} \\
\hline \multirow[t]{2}{*}{ SIZE } & -0.029 & -0.391 & -0.027 & -0.360 \\
\hline & {$\left[-5.32^{* * *}\right]$} & {$\left[-5.50^{* * *}\right]$} & {$\left[-4.78^{* * *}\right]$} & {$\left[-6.32^{* * *}\right]$} \\
\hline \multirow[t]{2}{*}{ FOREIGNERS } & 0.083 & 0.937 & 0.089 & 1.041 \\
\hline & {$\left[6.42^{* * *}\right]$} & {$\left[5.59^{* * *}\right]$} & {$\left[6.41^{* * *}\right]$} & {$\left[5.63^{* * *}\right]$} \\
\hline \multirow[t]{2}{*}{ CONSTANT } & 0.911 & 2.548 & 0.912 & 2.536 \\
\hline & {$\left[70.47^{* * *}\right]$} & {$\left[16.49^{* * *}\right]$} & {$\left[70.41^{* * *}\right]$} & {$\left[15.44^{* * *}\right]$} \\
\hline $\mathrm{N}$ & 1,620 & 1,620 & 1,620 & 1,620 \\
\hline Prob > F: & 0.000 & N/A & 0.000 & N/A \\
\hline Prob > Chi2: & N/A & 0.000 & N/A & 0.000 \\
\hline $\mathrm{R}^{2}:$ & 0.1752 & 0.0752 & 0.1381 & 0.0589 \\
\hline $\begin{array}{l}\text { Control variables - } \\
\text { Sectors }\end{array}$ & Yes & Yes & Yes & Yes \\
\hline Estimation: & POLS robust & FRACREG Logit robust & POLS robust & FRACREG Logit robust \\
\hline Average VIF & \multicolumn{2}{|c|}{2.92} & \multicolumn{2}{|r|}{2.99} \\
\hline \multicolumn{5}{|l|}{ Chow's Test } \\
\hline F-Statistics & $49.29^{* * *}$ & N/A & $42.38^{* * *}$ & N/A \\
\hline \multicolumn{5}{|l|}{ Breusch-Pagan's Test } \\
\hline $\mathrm{Chi}^{2}$ : & $2,955.10^{* * *}$ & N/A & $2,988.98^{* * *}$ & N/A \\
\hline \multicolumn{5}{|l|}{ Hausman's Test } \\
\hline $\mathrm{Chi}^{2}$ Statistics: & $26.58^{* * *}$ & N/A & $20.04^{* * *}$ & N/A \\
\hline
\end{tabular}

Null Hypothesis Rejection: *** 1\% Significance; ** 5\% Significance; * 10\% Significance.

Source: Research data (2011 to 2016).

proposed in $\mathbf{H}_{3}$ is confirmed concerning both significance and causal direction. In other words, chains with greater presence in shopping malls have a greater proportion of their own stores. As proposed in the $\mathbf{H}_{\mathbf{3}}$ formulation, we expect that the monitoring effect would be facilitated by the fact that the administration of these condominiums have interest on the performance of these outlets (part of the rent charged on shopkeeper is variable over the outlet income). However, we cannot disregard the fact that ventures like these provide a kind of forced demand, resulting from the attraction of consumers to it-so-called anchor stores. Consequently, sales performance tends to be better, increasing the chain's interest in enjoying such potential with a unit of its own (Carter \& Vandel, 2005). Distinguishing the influence of these two effects, it would be an interesting proposal of future works, given the symbiotic (and little studied) relationship between shopping malls and franchises. 
BBR

16,4

$\mathbf{H}_{4}$ is also strongly supported by our data in all models. That is, franchised chains that grew in size during the analyzed period increased the proportion of company-owned stores. This result seems to corroborate the hypothesis of property redirection (Oxenfeldt \& Kelly, 1968), which advocates that successful chains tend to either reduce the sale of new franchises or buy back existing franchises (or a combination of these). Literature is somewhat ambiguous about that. The results for SIZE presented in Table 5 coincide with Dant and Kaufmann (2003) and Dant, Perrigot and Cliquet (2008), however, are opposite to Shane (1998) and Alon (2001). Windsperger and Dant (2006) confirm the hypothesis of ownership redirection in Austria, but in a different perspective from the scarce resource view: The growth of the proportion of company-owned outlets is a consequence of a smaller allocation of intangible assets to franchisees, which makes the measurement of local performance more objective and less subject to noise. In our study, we don't develop this derived hypothesis, but our results (like those seen in Windsperger \& Dant, 2006) open space for future research.

Despite the inconvenience of the high level of correlation between AGE and TFRANCHISE, our robustness tests - as already mentioned - do not indicate threats to the validity of the model. In addition, the opposite signs of both variables illustrate peculiarities of the franchising in Brazil, which alone makes it worth using both variables in our models. As indicated in models 1 and 2, the older the chains become, the more they increase their percentage of company-owned stores. On the other hand, chains which have been franchising for a longer period are increasing the proportion of franchised outlets. Curiously, both variables are positively correlated $(\mathrm{r}=0.487)$, but these facts are not unseen in literature. Lafontaine (1992) had already observed that older chains tend to operate with more company-owned outlets, especially chains that were not franchising for a long time.

MATURITY is used in models 3 and 4. It combines the effects of both chain total age and chain experience with the franchising system, as previously mentioned. MATURITY presents significance at $1 \%$, but its direction is opposite to what is predicted in $\mathbf{H}_{5}$. Interestingly, in addition to going against $\mathbf{H}_{5}$, this result draws attention by counteracting the effect of SIZE. That is, if property redirection hypothesis is accepted, at the same time, SIZE seems to relieve the constraints that encourage using franchise, while experience does not seem to be a relevant factor related to scarce resources. Alternatively, as in Lafontaine (1992), our study points to what seems to be a path dependence effect: chains that have worked for a long time without adopting franchising tend to increase the proportion of their company-owned stores when restrictions on access to resources falls. As a result, we understand that the expected effect for the maturity construct $\left(\mathbf{H}_{5}\right)$ is partially supported.

Finally, $\mathbf{H}_{6}$ is not supported: The CAPINVST's signal is contrary to our expectations. Because of this, an alternative model was tested using the average value between the minimum and maximum values for the initial investment reported by the networks in the ABF yearbook. Even doing so the results we found were very similar to those shown in Table 5. Considering installation costs (and probably operational costs), our results seem to indicate that the more expensive it is to open a new unit, the greater the investment needed to open a new outlet, the greater the trend to increase the company-owned outlets proportion. We think about two alternative explanations for this result. First, due to the momentum in Brazilian economy, chains may not be able to attract or even keep franchisees in operation for both new and existing stores throughout this analyzed period. Second, chains are just taking advantage of the moment to repurchase some units, which would characterize a strategic movement. As verified in the non-rejection of $\mathbf{H}_{4}$, larger chains are increasing their proportion of company-owned outlets, which converges for this interpretation. 


\section{DISCUSSION AND CONCLUSION}

The dynamics of franchising contractual mix is a topic rather studied in literature, mostly in markets such as the USA and Europe, and under both agency and resource scarcity theories (Nijmeijer, Fabbricotti, \& Huijsman, 2014) However, the Brazilian market has been almost neglected by the investigative effort regarding the influence factors such as agency costs and resources hard to access. Our study revisits the topic based on these theoretical lenses, having some peculiarities as justification. First, the Brazilian scenario differs from the traditional markets treated in the literature in terms of economy, culture and institutions. Second, the dimensions of Brazil and its internal differences make the dispersion an interesting focus in investigations of retail and service networks. Finally, Brazil has experienced a deep economic and political crisis since 2014, which makes the scenario even more interesting in the scientific sense.

Relationships between geographic dispersion and more franchised outlets are recurrent in literature, which is amply demonstrated above. However, our paper extends the concept of dispersion to capture socioeconomic differences between the country regions. Less consolidated markets which have emerged because of the years of growth since the 1990s were occupied by chains through franchised units, which would satisfy both the convenience of distributing risks to contracted partners (franchisees) and the need to establish incentive mechanisms of local agents. Future research aimed at measuring the individual effect of these two vectors would be welcome.

Also, the expected (and confirmed) lower use of franchises in shopping malls supports the view of agency theory regarding costs of coordination and monitoring. However, it cannot be ignored that stores located in shopping malls tend to deal with conditions of differentiated demand compared to street stores, given the convenience offered by these enterprises (convenience, food, leisure, and mostly in Brazil: safety). Accepting this point of view, the chains would have incentives to seek to benefit from this greater potential profitability. Again, a future research opportunity to decouple these effects opens. In addition to the direct contribution, such research would cover a strange gap in literature: the lack of studies aimed at analyzing the relationship between shopping malls and franchise chains.

The old hypothesis of property redirection seems "current" in Brazilian data. In fact, chains that grew did so through more company-owned outlets. This increase in, say, vertical integration level is noticed in networks whose investment required to open a new unit increased during the period. Our data do not allow us to verify if this effect is a direct result from the bad economic moment. Future studies analyzing networks growth can help us understand whether our results indicate (i) a contractual mix strategy (taking advantage of the reduction in the franchised stores' assets value) or (ii) if what happens is the closing of franchised units due to the economic recession (which would increase the proportion of own stores). Similarly, what we find regarding the effect of greater seniority is intriguing. Older businesses - considering the age and not the franchise inception - have increased the franchised ratio. The opposite occurs with networks that have been franchising for longer (regardless of age). As mentioned before, a path dependence effect impregnated on the culture of the organization may lie at the heart of the explanation. However, we understand that deeper investigation is needed.

In short, our study revisited an important issue regarding the arrangement of franchises. More than identifying peculiarities of the Brazilian scenario, we bring some little explored factors such as the relation between franchising and shopping malls and the presence of Brazilian chains in less consolidated internal markets. However, we are aware of some limitations of the study, which may characterize future research opportunities. First, much
BBR

16,4 
BBR 16,4 of the information we use is provided as an average for the entire network (average revenue per outlet, for example.). Second, the influence of shopping mall presence needs to be more detailed. Neither can we identify whether the chain (i) maintains outlets in a shopping mall as a marketing channel strategy, (ii) whether it seeks to benefit from the monitoring carried out by the management of the shopping mall nor even if "(ii)" is a consequence of "(i)". Third, although our study is longitudinal, with gains of internal validity in the proposed causal relations, it is an additive one. Future studies proposing intervenient and/or moderating relations are welcome. Finally, agency theory and the vision of scarce resources have provided interesting answers and increased our understanding of the franchise industry. New strands (e.g., tournament theory and dynamic capabilities) and new problems (multiunit franchisees, social franchises, etc.) require researchers to take new steps to widen what we know about the arrangement.

\section{REFERRENCES}

Alon, I. (2001). The Use of Franchising by US-Based Retailers. Journal of Small Business Management, $39(2), 111-112$.

Antia, K. D., Zheng, X., \& Frazier, G. L. (2013). Conflict management and outcomes in franchise relationships: The Role of Regulation. Journal of Marketing Research, 50(5), 577-589.

Associação Brasileira de Franchising. (2014). Retrieved February 03, 2019, from https://www.abf.com.br/ abf-e-abrasce-divulgam-estudo-inedito-sobre-franquias-e-shoppings-no-brasil/

Associação Brasileira de Franquias. (2017). No Title. Retrieved from https://www.abf.com.br/numeros-dofranchising/

Associação Brasileira de Shopping Centers (2018). Números do setor. Retrieved January 18, 2019, from www.portaldoshopping.com.br

Baena, V. (2012). Market conditions driving international franchising in emerging markets. International Journal of Emerging Markets, 7(1), 49-71.

Bardonaba-Juste, V., Lucia-Palacios, L., \& Polo-Redondo, Y. (2011). An analysis of franchisor failure risk: evidence from Spain. Journal of Business and Industrial Marketing, 26(6), 407-420.

Bitti, E. J. S., Aquino, A. C. B., \& Amato, J., Neto (2013). Monitoramento e coordenação em redes de franquia: dispersão geográfica e automação impactando o mix contratual. Revista de Contabilidade E Organizações, 7(18), 3-13.

Brickley, J. A., \& Dark, F. H. (1987). The choice of organizational form the case of franchising. Journal of Financial Economics, 18(2), 401-420.

Brickley, J. A., Dark, F. H., \& Weisbach, M. S. (1991). The economic effects of franchise termination laws. The Journal of Law and Economics, 34(1), 101-132.

Carney, M., \& Gedajlovic, E. (1991). Vertical integration in franchise systems: Agency theory and resource explanations. Strategic Management Journal, 12(8), 607-629.

Carter, C. C., \& Vandel, K. D. (2005). Store Location in Shopping Centers: Theory and Estimates. Journal of Real Estate Research, 27(3), 237-265.

Castro, L. M. de, Mota, J., \& Marnoto, S. (2009). Toward a relational perspective of franchising chains. Service Business, 3(1), 15.

Castrogiovanni, G. J., Combs, J. G., \& Justis, R. T. (2006). Resource scarcity and agency theory predictions concerning the continued use of franchising in multi-outlet networks. Journal of Small Business Management, 44(1), 27-44.

Caves, R. E., \& Murphy, W. F. (1976). Franchising: Firms, markets, and intangible assets. Southern Economic Journal, 572-586.

Cliquet, G. (2000). Plural forms in store networks: a model for store network evolution. The International Review of Retail, Distribution and Consumer Research, 10(4), 369-387.

Cliquet, G., \& Pénard, T. (2012). Plural form franchise networks: A test of Bradach's model. Journal of Retailing and Consumer Services, 19(1), 159-167.

Combs, J. G., \& Castrogiovanni, G. J. (1994). Franchisor strategy: a proposed model and empirical test of franchise versus company ownership. Journal of Small Business Management, 32(2), 37-48.

Combs, J. G., \& Ketchen, D. J. (1999). Can capital scarcity help agency theory explain franchising? Revisiting the capital scarcity hypothesis. Academy of Management Journal, 42(2), 196-207. 
Combs, J. G., Ketchen, D. J., \& Short, J. C. (2011). Franchising Research: Major Milestones, New Directions, and Its Future Within Entrepreneurship. Entrepreneurship: Theory and Practice, 35(3), 413-425.

Combs, J., \& Ketchen, D. (2003). Why do firms use franchising as an entrepreneurial strategy? A metaanalysis. Journal of Management, 29, 443-465.

Dant, R. P., \& Kaufmann, P. J. (2003). Structural and strategic dynamics in franchising. Journal of Retailing, 79(2), 63-75.

Dant, R. P., Perrigot, R., \& Cliquet, G. (2008). A cross-cultural comparison of the plural forms in franchise networks: United States, France, and Brazil. Journal of Small Business Management, 42(6), 286-311.

Dnes, A. W. (1992). Unfair Contractual Practices and Hostages in Franchise Contracts. Journal of Institutional and Theoretical Economics, 148, 484-504.

Fladmoe-Lindquist, K., \& Jacque, L. L. (1995). Control modes in international service operations: The propensity to franchise. Management Science, 41(7), 1238-1249.

Garg, V. K., Priem, R. L., \& Rasheed, A. A. (2013). Theoretical Explanation of the Cost Advantages of Multiunit Franchising. Journal of Marketing Channels, 20(1-2), 52-72.

Gillis, W. E., Combs, J. G., \& Ketchen, D. J. (2014). Using resource-based theory to help explain plural form franchising. Entrepreneurship Theory and Practice, 38(3), 449-472.

Gomez, R. S., González, I. S., \& Vazquez, L. (2010). Multi-unit versus single-unit franchising: assessing why franchisors use different ownership strategies. The Service Industries Journal, 30(3), 463-476.

Hsiao, C. (1996). Analysis of panel data. Cambridge: Cambridge University Press.

Hsu, L., Kaufmann, P., \& Srinivasan, S. (2017). How Do Franchise Ownnership Structure and Strategic Investment Emphasis Influence Stock Returns and Risks? Journal of Retailing, 93(3), 350-368.

Kashyap, V., Antia, K. D., \& Frazier, G. L. (2012). Contracts, extracontractual incentives, and ex post behavior in franchise channel relationships. Journal of Marketing Research, 49(2), 260-276.

Lafontaine, F. (1992). Agency theory and franchising: some empirical results. The RAND Journal of Economics, 23(2), 263-283.

Lafontaine, F., \& Kaufmann, P. (1994). The Evolution of Ownership Patterns in Franchise Systems. Journal of Retailing, 70(2), 97-113.

Lafontaine, F., \& Shaw, K. L. (2005). Targeting managerial control: evidence from franchising. The RAND Journal of Economics, 36(1), 131-150.

Lemos, M. L. F., \& Rosa, S. E. S. (2003). O segmento de shopping centers no Brasil e o BNDES. BNDES Setorial, 17, 171-186.

Madanoglu, M., \& Castrogiovanni, G. J. (2017). Franchising proportion and network failure. Small Business Economics, 50(4), 697-715.

Maness, R. (1996). Incomplete contracts and the choice between vertical integration and franchising. Journal of Economic Behavior and Organization, 31(1), 1001-115.

Martin, R. E. (1988). Franchising and risk management. The American Economic Review, 954-968.

Minkler, A. P. (1992). Why firms franchise: a search cost theory. Journal of Institutional and Theoretical Economics, 148(2), 240-259.

Nijmeijer, K. J., Fabbricotti, I. N., \& Huijsman, R. (2014). Making franchising work: A framework based on a systematic review. International Journal of Management Reviews, 16(1), 62-83.

Norton, S. W. (1988). An empirical look at franchising as an organizational form. Journal of Business, 61(2), 197-218.

Norton, S. W. (1995). Is franchising a capital structure issue? Journal of Corporate Finance, 2(1), 75-101.

Oxenfeldt, A. R., \& Kelly, A. O. (1968). Will Successful Franchise Systems Ultimately Become Whollyowned Chains? Journal of Retailing, 44(4), 69-83.

Papke, L. E., \& Wooldridge, J. (1996). Econometric methods for fractional response variables with an application to 401 (k) plan participation rates. Journal of Applied Econometric, 11(1), 619-632.

Papke, L. E., \& Wooldridge, J. M. (2008). Panel data methods for fractional response variables with an application to test pass rates. Journal of Econometrics, 145(1), 121-133.

Pashigian, B. P., \& Gould, E. D. (1998). Internalizing externalities: the pricing of space in shopping malls. The Journal of Law and Economics, 41(1), 115-142.

Rubin, P. H. (1978). The Theory of the Firm and the Structure of the Franchise Contract. The Journal of Law and Economics, 21(1), 223-233.

Shane, S. A. (1996). Hybrid organizational arrangements and their implications for firm growth and survival: A study of new franchisors. Academy of Management Journal, 39(1), 216-234.

Shane, S. (1998). Explaining the distribution of franchised and company-owned outlets in franchise systems. Journal of Management, 24(6), 717-739. 
Silva, V. L. S., \& Azevedo, P. F. de. (2007). Formas plurais no franchising de alimentos: evidências de estudos de caso na França e no Brasil. Revista de Administração Contemporânea, 11, 129-152.

Teller, C., \& Schenedlitz. (2012). Drivers of agglomeration effects in retailing: The shopping mall teenant's perspective. Journl of Marketing Management, 28(9-10), 1043-1061.

Thompson, R. S. (1994). The franchise life cycle and the Penrose effect. Journal of Economic Behavior e Organization, 24(2), 207-218.

United Nations Development Programme (UNDP). (2018). Recuperado de http://hdr.undp.org/en/content/ human-development-index-hdi

Windsperger, J., \& Dant, R. P. (2006). Contractibility and ownership redirection in franchising: A property rights view. Journal of Retailing, 82(3), 259-272.

Wooldridge, J. M. (2010). Econometric analysis of cross section and panel data. Cambridge: MIT press.

There is no conflict of interest between authors. All the authors contributed with the idea, elaboration, data collection and finalization of the article. The first author is the idealizer of the research, who also contributed to the development, conclusion and finalization of the article. The second author contributed to the econometric estimations, as well as the robustness checks. The third author contributed to data collection and processing, as well as, in the development of the article. 